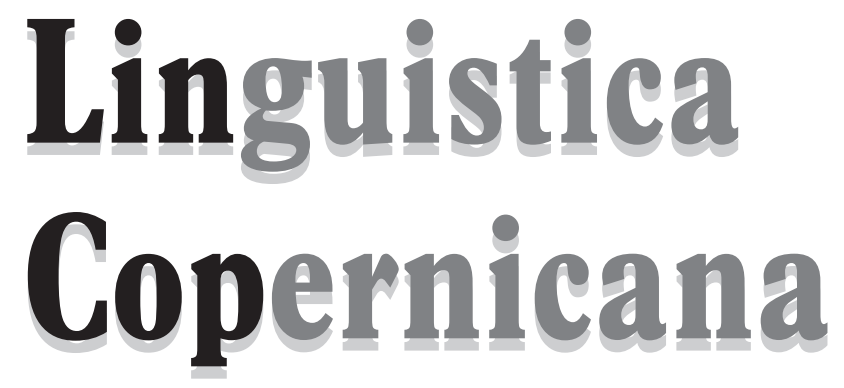

$1(7) / 2012$

WYDAWNICTWO NAUKOWE
UNIWERSytetu MIKOLAJa KOPERNIKA 
REDAKTOR NACZELnY: Maciej Grochowski

Rada Redakcyjna: Ireneusz Bobrowski (Kraków), Andrzej Bogusławski (Warszawa), Gerd Hentschel (Niemcy, Oldenburg), Axel Holvoet (Litwa, Wilno), Krystyna Kleszczowa (Katowice), Roman Laskowski (Kraków), Jarmila Panevová (Czechy, Praha), Jens Nørgård-Sørensen (Dania, Kopenhaga), Zuzanna Topolińska (Macedonia, Skopje), Daniel Weiss (Szwajcaria, Zurich), Anna Wierzbicka (Australia, Canberra)

Kole gi u m R e D K C Y J e: Maciej Grochowski, Krystyna Kallas, Irena Sawicka, Piotr Stalmaszczyk

S E K R ETA R Z R E D A K C I: Iwona Kaproń-Charzyńska

A D R E S R E D A K C J I: Instytut Języka Polskiego UMK, 87-100 Toruń, ul. Fosa Staromiejska 3, e-mail: lincop@umk.pl,www.linguistica.umk.pl

OKŁ A D K A: Monika Pest

(C) Copyright by Wydawnictwo Naukowe Uniwersytetu Mikołaja Kopernika

Toruń 2012

ISSN 2080-1068

Wersją pierwotną (referencyjną) czasopisma jest wersja papierowa.

WYDAWNICTWO NAUKOWE UNIWERSYTETU MIKOEAJA KOPERNIKA

Redakcja: ul. Gagarina 5, 87-100 Toruń

tel. (56) 6114295 , tel./fax 6114705

e-mail: wydawnictwo@umk.pl

Dystrybucja: ul. Reja 25, 87-100 Toruń

tel./fax (56) 61142 38, e-mail: books@umk.pl

www.wydawnictwoumk.pl

Druk: Wydawnictwo Naukowe UMK 
Andrzej BogusŁaWski

\section{Nota o TRS i o tezie 7 Wittgensteina}

Słow a klucze: struktura tematyczno-rematyczna, temat, remat, dictum tematyczne, apozycja, parentetyczność, pierwsza osoba, indeks, subskrypt

Te uwagi na temat TRS (jak będę, anglogennie, nazywać ogół zjawisk dotyczących wiadomej struktury zdaniowej), jakie chcę tu przedstawić, będą dotyczyć jedynie pewnych cząstek rozległej problematyki.

Zgodnie ze zgłoszonym tytułem, chodzić mi będzie o zjawiska, które mogą się kojarzyć z 7 tezą zamykającą w sposób wielce sentencjonalny Traktat Wittgensteina. Jak pamiętamy, brzmi ona: Wovon man nicht sprechen kann, darüber muß man schweigen. / O czym nie można mówić, o tym trzeba milczé́.

Filozofowie traktowali tę tezę często jako podsumowanie zwłaszcza tez szóstych Traktatu z ich akcentami mistycznymi, z ich wskazaniami na istnienie rzeczy ,pozaświatowych”. W tej perspektywie istotnie aż się prosi interpretacja tezy 7 jako wyrazu ogólnej zadumy autora nad Rzeczywistością i jej tajemnicami lub tajemnica, zadumy przywołującej wyraziście swym klimatem, ale i konkretnym wysłowieniem, na przykład główne wątki taoizmu chińskiego. (Po rosyjsku powiedziałoby się, nieco ironicznie, tak: Witgiensztejn wyskazatsja gtubokomyslenno.)

Można jednak, jak sądzę, zwłaszcza w nawiązaniu do pozytywistycznych inklinacji Wittgensteina, którym daje on wyraz w tezach wcześniejszych (ale 
także pospołu z tezami „mistycznymi”), znaleźć inną, bardziej empirystyczną, interpretację jego myśli siódmej. A w każdym razie można zobaczyć w niej odskocznię dla sformułowania pewnych obserwacji lingwistycznych, i to właśnie w odniesieniu do TRS.

Zgodnie z tym punktem widzenia skłonny jestem potraktować tezę 7 jako kierującą naszą uwagę ku pewnemu raczej przyziemnemu faktowi. Przypomnijmy, że autorowi Traktatu najbardziej zależało na ukazaniu prawdocentrycznej bazy języka, tej tkwiącej w zdaniach, jak je swoiście nazywał, „sensownych". Otóż, jak się wydaje, zdał on sobie sprawę, i to tak, jak mało kto, że jeżeli obecność tej bazy ma być podniesiona do rangi niezbywalnego kanonu teorii języka, to nie da się tego zrobić inaczej niż porzucając nadzieję na to, że obok ws zystkich szczegółów rzeczywistości zewnętrznej w ich układankach po prostu postawimy zawsze ściśle p a ra le ln e odwzorowania w postaci sztucznych (,dorobionych”) układów wyrażeń (językowych) i w ten sposób zamkniemy kwestię stosunku języka do rzeczywistości. Zgodnie z obserwacją Wittgensteina nie wszystko może być „opowiedziane” przez zawarcie tego w słowach. Muszą też istnieć punkty lub rysy świata zewnętrznego, które pokazujemy bezpośrednio, punkty i rysy, bez których udziału, udziału, by tak rzec, w ich własnej osobie, a nie per procura, oczywiście we współdziałaniu z treścią wyrażeń znaczących, nie ma efektywnego działania mownego. Dwa całkowicie autonomiczne, ściśle paralelne szeregi, szereg zjawisk zewnętrznych i szereg sztucznych erupcji wymówieniowych lub graficznych, nie stykające się i nie splatające ze sobą (i to z takim brakiem owego splotu, który byłby tej ich relacji właściwy konstytutywnie), mogą się odnosić do siebie tylko po kantowsku (lub po saussurowsku). W tym ujęciu mielibyśmy z jednej strony bliski nam szereg językowy, w którym się jakoś rozeznajemy, a z drugiej szereg zewnętrzny, o którym ostatecznie nie wiemy nic poza tym, że istnieje. Ten agnostyczny, zbliżający się do sceptyckiego, pogląd na język nie znajduje aprobaty u autora Traktatu. Jest zresztą rzeczą ogólnie znaną, że idea samoistnego „ukazywania się” logiki w kształtach zdaniowych, w odróżnieniu od jej oznaczania i opisywania, w których efektywność i nawet prawomocność Wittgenstein nie wierzył, jest jednym z leitmotiwów Traktatu, może nawet jego leitmotiwem sztandarowym. Ze swej strony przyłączam się w każdym razie do antysceptyckiej opozycji młodego Wittgensteina i do jego idei wprowadzenia „pokazów”, nie: opisów, niejako in medias res. 
Maksyma „trzeba o pewnych rzeczach milczeć” przy naszkicowanej interpretacji stanowiłaby, w odniesieniu do patrzenia na mowę ludzką, po prostu przestrogę przed uleganiem iluzji, jakobyśmy mogli zawsze zastapić, w całościowej analizie wypowiedzeń przedmiotowych, ich właściwości - osobnymi elementami słownymi, oraz wezwanie do tego, by pewne właściwości wskazywać niejako „palcem” (ten palec może być wspomagany takim czy innym słowem zewnętrznym; ale nie będzie to słowo wtopione w jakąś narrację zastępującą oryginalny tekst, jaki poddajemy obserwacji; i nie będzie to też takie jego ,glosowanie”, któremu przyświecałaby ostatecznie idea prostej, a zarazem wyczerpującej substytucji równoważnościowej).

Jako „flagowy” przykład takiej właściwości wskazywanej palcem podałbym, myślę, że w zgodzie z Wittgensteinem, taką oto „(ścisłą) tożsamość”. W zdaniu On oddat jej ksiażkę. tożsamość książki pożyczonej i zwróconej jest zag waranto wan a przez sam fakt, że mamy do czynienia z numerycznie jednym czasownikiem (mianowicie: czasownikiem oddat / oddać).

Otóż pierwszą rzeczą, jaką trzeba powiedzieć o TRS, jest to, że sama ta struktura jako całość nie jest przekładalna na jakiekolwiek środki werbalne. Można powiedzieć, że TRS jest czymś w wittgensteinowskim sensie „ukazującym się", co więcej, czymś ,ukazującym się" par excellence. Trzeba to uznać pod grozą regresu nieskończonego. Wskazałem na tego rodzaju zagrożenie w recenzji habilitacyjnej Anny Wierzbickiej Dociekań semantycznych (1969), w których autorka próbowała uchwycić werbalnie temat i remat - ten pierwszy za pomocą myślę o, ten drugi - za pomocą mówię. A więc za pomocą wyrażeń, które przecież same są wmontowane w układy tematyczno-rematyczne. (Dodam, że skądinąd śmiałą ambicję niejako „dotknięcia palcem” fenomenów tematu i rematu, zamiast wprowadzania kolejnych etykietek, ambicję, która stała za jej próbą, trzeba niezwykle cenić.)

Ze swej strony podtrzymuję ujęcie TRS późniejsze niż to, jakie podałem w książce z r. 1977. To późniejsze ujęcie ma dwa filary. Po pierwsze, odnosi ono TRS nade wszystko do bazowego stratum języka, jakie stanowią zdania powiedziane na poważnie w trybie 'powiedział, że', ale także jakie stanowi semantyka ich propozycjonalnie zamkniętych składników, np. metatekstowych (w odróżnieniu od rozmaitych rzeczy „cytacyjnych”, a także „urwanych", lub niektórych wypowiedzeń niepodzielnych). Po drugie, moje ujęcie przyrównuje „temat” do obiektu epistemicznego, najczęściej zewnętrznego, a „remat” do atrybutu czy też askrypcji, tak jak te funkcjonują w składzie 
argumentów funktora wie, że (mianowicie w uniwersalnym prefiksie oznajmującym 'ktoś wie, że'). To ten funktor funduje owo centralne zjawisko językowe, któremu na imię powiedziat, że. Funktor wie, że jest niedefiniowalny, ale czteroargumentowy. Odpowiednio do tego ukształtowanie zdania w pełni, w sposób jawny, zewnętrzny, realizującego 'powiedzenie, że', ukształtowanie jakoś korespondujące $\mathrm{z}$ argumentami funktora 'wie, że', musi być czwórdzielne. Tym zaś, co dla nas jest szczególnie istotne z punktu widzenia obecnie rozważanego wątku myślowego, jest fakt, że ta czwórdzielność jest dostępna wylącznie perceptybilnie i bezpośrednio, a $\mathrm{n}$ i e przez pryzmat jakichkolwiek wyspecjalizowanych translatów słownych.

Od tej najogólniejszej windykacji potrzeby swoistego „milczenia” wokół TRS przejdę do paru obserwacji bardziej szczegółowych dotyczących naszej struktury. Chodzić będzie o zjawiska, w odniesieniu do których podobne „milczenie” jestem gotów również uznać za zalecone.

Po pierwsze, powiem o sprawie części presupozycyjnej, czy też o sprawie, jak rzecz bywa nazywana, dictum tematycznego, ściślej: dictum w szerokim sensie „apozycyjnego" (tematyczne niedemonstratywne deskrypcje określone lub nieokreślone [podaję tu jedynie wstępną charakterystykę zakresu wyrażeń, jaki mam na myśli] wymagają osobnego podejścia, mianowicie implikacyjnego; o nich teraz mówić nie będę; powiem tylko, że takie te ma tyc z ne „deskrypcje” są zasadniczo różne od „d i c ta lno-t e ma tycznych” apozycji).

Jak wskazywałem w dawnym artykule (1973), do zawartości dictum tematycznego typu (Franco), dyktator Hiszpanii, [...] w zdaniach podlegajacych jako całość określeniu powiedziat, że jest tak a tak nie można zarazem idiomatycznie i całkowicie przezroczyście odnieść tej samej kwalifikacji powiedział, że; można to zrobić tylko z wyraźnym przesunięciem ad hoc zakresu funktora powiedziat, $\dot{z} e$. Gdyby bowiem zastosowanie kwalifikacji powiedział, że było bez żadnych zastrzeżeń możliwe w odniesieniu do takich „apozycji”, to zdania zawierające je nie różniłyby się w sposób istotny od zdań z koniunkcją wchodzących w grę predykatów w remacie, takich jak zdanie Franco byt dyktatorem Hiszpanii i był współodpowiedzialny za zbombardowanie Guerniki. Tymczasem istotna różnica między wiadomymi zdaniami zachodzi ponad wszelką wątpliwość. Ona to w gruncie rzeczy jest w zapleczu samej idei osobnej ingrediencji zdaniowej w postaci owego dictum tematycznego. 
Przedstawię wstępną myśl dotyczącą sposobu zdania sprawy z osobliwości tej ingrediencji. Może jest tak, że wyodrębnienie tematyczno-dictalne wiąże się z czynnością mówiącego, którą $w$ tym punkcie trzeba określić jako nie więcej niż powiedział o [kimś / czymś]: _ (w naszym przykładzie: dyktator Hiszpanii), a więc jako swoiste ,powiedzenie cytacyjne” (oczywiście owo „ktoś / coś” odnosi się do istot lub rzeczy aktualnie wchodzących w grę). Takie powiedzenie, przyjmuję, jest stanowczo odróżniane od 'powiedzenia, że', a ponadto w ogólnej ekonomii języka jest czymś wtórnym i drugorzędnym. Tego rodzaju status ,apozycji” przyjmuje przy tym w odpowiednich wypadkach mownych, moim zdaniem, nie tylko lingwista; jest to coś, co każdy odbiorca gotów jest uznać za stronę funkcjonalną wchodzących w grę wyrażeń. Powiedziałbym mianowicie, że ta strona funkcjonalna polega na umożliwieniu odbiorcy uświadomienia sobie, iż mówiący jest gotów powiedzieć, że tak a tak (np. że Franco był dyktatorem Hiszpanii).

Rzeczą główną, która mnie tu interesuje, jest jednak pewna dalsza rzecz. Podobnie jak w ogóle podział na część tematyczną i rematyczną nie daje się zastapić opisem słownym, tak również dictum tematyczne ma swe niewerbalizowalne znamiona perceptybilne. Na miejsce środków wiadomego wyodrębnienia DT nie można wstawiać np. zwrotu daję ci do zrozumienia, że możesz uświadomić sobie, iż jestem gotów powiedzieć, że ... czy też innego zwrotu pokrewnego - w roli zwrotu równoważnie użytego przez samego mówiqcego.

Dlaczego nie można tego robić? Dlatego mianowicie, że na miejsce naszych, nazwijmy to tak, apozycji wprowadzilibyśmy rzecz zasadniczo inną: normalne zdania, tyle że ujęte parentetycznie; por. Franco (daje ci do zrozumienia, $\dot{z} e$ itd.) ... W tych zdaniach parentetycznych, zwróćmy uwagę, mogłyby się pojawiać kolejne apozycje odnoszące się do mówiącego, por. np.: ja, skadinad słabo zorientowany w tych sprawach, daje ci do zrozumienia, że itd.; analogiczna zaś eliminacja tych kolejnych apozycji na rzecz autoopisów wymagałaby kontrintuicyjnego rekurencyjnego konstruowania wtrąceń parentetycznych coraz niższego stopnia, por.: Franco (daję ci do zrozumienia [daje ci do zrozumienia, że możesz sobie uświadomić, iż jestem gotów powiedzieć, że skadinad jestem słabo zorientowany $w$ tych sprawach], że możesz sobie uświadomić, iż jestem gotów powiedzieć, że Franco byt dyktatorem Hiszpanii) był współodpowiedzialny za zbombardowanie Guerniki.

Druga kombinacja obserwacji i domysłu, jaką chciałbym zasygnalizować w związku ze sprawą „niewerbalizowalności” pewnych informacji, dotyczyć 
będzie indeksu egocentrycznego w postaci wyrazu ja lub jego synonimów typu mówiqcy te słowa względnie osobnych wykładników fleksyjnych 1 osoby lp, a także w postaci elementu treściowego synkretycznie ukrytego w wyrażeniach $\mathrm{w}$ rodzaju demonstrativum ten $\mathrm{z}$ jego wykładnią parentetyczna 'wiesz, o kim / czym mówię' (przyjmuję, że taka wykładnia demonstrativum, jak starałem się pokazać w artykule z r. 1991, jest trafna).

Zacznę od stwierdzenia, że istnieją przypadki, kiedy nie sposób jest poprawnie zrozumieć konstrukcji zdaniowej bez przyjęcia jako tematu (nie: nazwy tematu!) - oczywiście jako tematu w stosunku do określonej predykacji, a więc w stosunku do określonego rematu - samego w sobie bieżącego wypowiedzenia; chodzi przy tym o sytuację, w której brak jest jakiegokolwiek towarzyszącego temu nazwania tego wypowiedzenia, a nawet osobnego jego przytoczenia. Przykładem może być, jak się zdaje, to, co zachodzi w okurencjach nieakcentowanej partykuły tylko, którą się niedawno zajmowałem.

Partykuła tylko może komentować to, co mówi aktualny mówiący, ale również to, co mówi ktoś inny, którego wypowiedź aktualny mówiący relacjonuje, por. Karol się tylko uśmiechnat. i Piotr powiedział, że Karol się tylko uśmiechnqł. Reprezentuje ona, tzn. partykuła tylko, ograniczenie przez użytkownika tego, co jest, jego zdaniem, do powiedzenia, do pewnej treści podanej w określonym tekście. Ale podanej komu przez kogo i w jakim tekście? Podanej właściwemu adresatowi przez tego, kto, jak można zrozumieć, wygłosił rzecz językową pokazana wprost $w$ danej okurencji wyrażenia skonfigurowanego z tylko, w naszym przykładzie - wyrażenia uśmiechnqł się. Otóż to, co nazwałem ,daną okurencją wchodzącego w grę wyrażenia”, jest zidentyfikowane przez przynależność do określonego jednostkowego tekstu. Ale żadna słowna charakterystyka nie wystarczy do adekwatnego zdania sprawy z tego, o jaki to tekst chodziło aktualnemu mówiącemu. Na przykład naprowadzanie na ten tekst za pomocą (parentetycznego co do swej natury) zaimka to, zaimka niosącego treściowo glosę 'wiesz, o czym mówię', np. przez użycie, powiedzmy, wtrąconej frazy ,uśmiechnat się” z tego wypowiedzenia, nie jest adekwatne. Taka fraza kazałaby słuchaczowi szukać dopiero odpowiedniego obiektu, w tym wypadku obiektu w postaci wypowiedzenia, w pewnej puli takich obiektów, tak jak się to dzieje w wypadku powiedzenia np. ten ołówek tam, gdzie mogą wchodzić w grę różne ołówki, gdzie jednak wyciągnięty palec jest bliższy tylko jednemu z nich. Tymczasem w wy- 
padku naszej partykuły tylko słuchacz praktycznie w 100\% wypadków wie doskonale, jaki tekst bierze pod uwagę aktualny mówiący: jest to tekst stanowiący poniekąd część jego samego, tego mówiącego - jako tekst właśnie produkowany lub reprodukowany przez niego. Aktualny mówiący może za pomocą glosy 'wiesz, o czym mówię' (synkretycznie zawartej w naszej partykule) podsunąć słuchaczowi treść suponowanego powiedzenia niesionego przez partykułę tylko. Ale może to zrobić dopiero wtedy, kiedy lokalizacja wiadomego powiedzenia została $u k a z$ an a słuchaczowi w sposób całkowicie niedwuznaczny, bez uciekania się do jakichkolwiek opisów lub nawet aluzji (w rodzaju właśnie glosy takiej jak 'wiesz, o czym mówię') - tzn. kiedy to powiedzenie zostało mu podsunięte wprost w bieżącym tekście w roli oryginału lub kopii (kopii w wypadku relacji dotyczącej innego mówiącego, jak w przykładzie Piotr powiedziat, że Karol się tylko uśmiechnat.) i kiedy słuchacz wie, że nic innego w ogóle nie może wchodzić nawet potencjalnie w grę.

Trzeba przyjąć, że tego rodzaju fragmenty rzeczywistości zewnętrznej są zawsze prawdziwymi tematami (nie: wyrażeniami tematycznymi, indeksami), podobnie jak sama woda utleniona w buteleczce jest tematem napisu woda utleniona na buteleczce. Frege, mówiąc o „myśli” jako znaczeniu zdania, nie chciał uznać realnego Mont Blanc za składnik myśli. Jego zastrzeżenie brzmi przekonywająco - kiedy zderzymy rzecz z asocjacjami, jakie niesie ze sobą słowo myśl. Wystarczy jednak uświadomić sobie, że wyrażenie jest wysoki oddaje (ewentualną) wiedzę, że Mont Blanc jest wysoki, by uznać, że jest taka rzecz zdaniowa, której składnikiem jest ni mniej ni więcej tylko właśnie Mont Blanc w całej swej okazałości, nic innego.

Zapytajmy teraz, już bezpośrednio odnosząc się do wspomnianego centralnego wyrażenia, jakim jest ja: jak się ma to wszystko do kwestii jego natury? I ogólniej: jak poprawnie zdać sprawę z roli tego wyrażenia?

Wprowadzę naprzód kilka stwierdzeń negatywnych.

'Ja' nie może być deskrypcją określoną opartą na jedynym wchodzącym w grę predykacie, mianowicie predykacie 'mówi' i niczym więcej. Taka deskrypcja odwoływałaby się bowiem do czyjegoś mówienia czegokolwiek albo choćby tylko tego, co jest aktualnie powiedziane (np. w wypadku zdania Jestem chory. - że taki a taki jest chory). Tymczasem tego rodzaju desygnatów, tzn. osób mówiących to, jest albo może być mnóstwo. To przekreśla założoną ,jedyność”, a wraz z tym poprawne przypisanie $j a$ statusu 
deskrypcji określonej. W wypadku ja może chodzić wyłącznie o jedyność aktualnego wypowiedzenia, w którym zostaje użyte właśnie wyrażenie ja lub jego ekwiwalent. Wszelako to wypowiedzenie samo miałoby obejmować podanie suponowanej deskrypcji określonej. Tymczasem użycie deskrypcji polegające na skonstruowaniu deskrypcji tego, kto właśnie konstruuje tę właśnie deskrypcję, prowadzi bezpośrednio do regresu nieskończonego. Otrzymujemy bowiem charakterystykę tej jedynej osoby jako kogoś, kto konstruuje deskrypcję kogoś, kto konstruuje deskrypcję kogoś, kto ... itd., in infinitum. Brak możliwego zamknięcia deskrypcji, jaką się ma na widoku (i bez której zamknięcia nie ma, analitycznie, w ogóle żadnej deskrypcji), jest więc oczywisty.

Dalej, ja nie może być eksponentem pojęcia stojącego obok pojęcia 'ktoś', w pozycji równorzędności z nim, tak jak to prezentuje obraz „prymitywów” Wierzbickiej. Oczywiście, jest prawdą, że nie do każdego obiektu, do którego zostaje odniesione 'ktoś', zostaje też odniesione 'ja' (także dlatego, że Siwek nie używa tego ostatniego, choć pojęcie 'ktoś' obejmuje i jego, Siwka). Ale do każdego obiektu, do którego zostaje odniesione 'ja', odnosi się również wyrażenie 'ktoś'. O niezależnym od 'ktoś' prymitywie 'ja' nie może być mowy.

Kolejny punkt negatywny. Ja nie może być eksponentem pojęcia obejmującego predykat 'mówi' wraz z podaniem już nie nazwy jego konkretnego, jedynego argumentu przedmiotowego w postaci wytworu tego 'mówienia' (to, jak widzieliśmy, jest niemożliwe bez regresu), lecz nawet wraz z materialnym, by tak rzec, podaniem samego tego argumentu / tematu przedmiotowego, jakim jest jednostkowe aktualne zdanie czy wypowiedzenie, zdanie lub wypowiedzenie wzięte bezpośrednio z rzeczywistości zewnętrznej i nie opisywane już słownie, lecz po wittgensteinowsku ,ukazywane”. Propozycję zrobienia z 'ja' takiej właśnie quasi-deskrypcji określonej bez zamknięcia słownego, a za to z jej zamknięciem przez wyjście ku realnemu, namacalnemu wypowiedzeniu, zgłosiłem w swym artykule o ‘ja' i ‘ty' (w książce z r. 1998).

Jest to propozycja nie do utrzymania. Co więcej, jak pokażę, jest to propozycja absurdalna, i nawet trywialnie absurdalna (niestety, nie pojawiło się żadne dziecko, w tej liczbie takie, jak ja, które by powiedziało: „szefie, jesteś nagi!'). Dlaczego jest to propozycja absurdalna? Dlatego, że po to, by można było skorzystać z owego przedmiotu w postaci aktualnego wypowiedzenia jako współtworzącego rzeczywistą strukturę, powiedzmy, dwuargu- 
mentową, opartą na predykacie 'mówi', zastosowanie tego predykatu i jego przedmiot (ten drugi, nieagentywny) musiałyby być odrębne od aktualnego mówienia. Tymczasem to, o co mi szło, implikowało właśnie odniesienie użytego przez nadawcę predykatu 'mówi' do numerycznie identycznego jego użycia, a więc dokonywanie na sobie przez nadawcę podwójnej predykacji: predykacji np. choroby (dla przykładu: Jestem chory.) i predykacji tej właśnie predykacji.

Zasugerowałem się oczywistym związkiem 'ja' z mówieniem, związkiem, który nie został uwzględniony w obrazie Wierzbickiej. Ale kiedy się przechodzi, skądinąd rozsądnie, od czyjegoś użycia ‘ja' do myśli „ktoś powiedział coś” jako implikowanego przez użycie 'ja', to trzeba zapytać: dobrze, ale kto przeprowadza taką inferencję? Może ją przecież przeprowadzać słu ch a c z wypowiedzi, w której wystąpiło ja. Nie musi tego bynajmniej robić mówiący w momencie użycia przez siebie wyrazu ja. Co więcej, mówiący nawet nie może traktować 'ja' jako charakteryzującego jego samego przez przypisanie mu roli agensa bieżącego aktu mówienia. Wystarczy się przyjrzeć, teoretycznie możliwej, sekwencji mówię, że mówię, że mówię, $\dot{z} e$...: każde mówię odnosi się tu do innego, następnego; żadne nie odnosi się do mówienia realizowanego przez użycie jego samego, tzn. danej okurencji mówię.

I jest to rzecz najogólniejsza: mówienie, podobnie jak wszelkie robienie czegoś, nie może mieć za swój przedmiot siebie samo. Wracamy tu do tego, o czym jako o niemożliwości logicznej mówiłem przed chwilą (w odcinku poprzedzającym ten, jaki poświęciłem Wierzbickiej). Warto wspomnieć, że tego rodzaju wykluczenie samozwrotności dotyczy także drugiego obok 'zrobić' zjawiska absolutnie pierwotnego, mianowicie 'wiedzy, że' (w ścisłym sensie koreferencjalne , $a$ wie, że $a$ wie, że ...” jest niemożliwe; w tym miejscu nie mogę omawiać w szczegółach tego problemu, który skądinąd wykazuje pewne komplikacje i rzeczywiście wymagałby dodatkowych komentarzy).

To, co powiedziałem, trzeba uzupełnić uchyleniem możliwego zarzutu nieuwzględnienia kontrprzykładu. Ktoś mógłby mianowicie wskazać, że są w użyciu wyrażenia takie, jak powiadam, mówię ci, jak mówię itp. wchodzące do bieżącego zdania; por. On jest, jak powiadam, niemadry. Ten zarzut byłby jednak nietrafny: tu chodzi o wyrażenia metatekstowe, których odniesienie jest, wbrew pozorom, zewnętrzne, mianowicie zewnętrzne w stosunku do tekstu z tzw. object level. W takich wyrażeniach o żadnej zakazanej sa- 
mozwrotności mowy być nie może. Co się zaś tyczy przypadków takich, jak zilustrowany wyżej przy pomocy partykuły tylko, to trzeba pamiętać o tym, że nie ograniczają się one do aktualnego mówiącego, bo dotyczą także mówiących, o których mówi aktualny mówiący, por. Piotr powiedziat, że Karol się tylko uśmiechnat.

Cóż więc pozostaje jako możliwa pozytywna odpowiedź na pytanie o rolę 'ja'?

Przypomnę, że kiedy mamy do czynienia z konieczną wielością bytów, do każdego z których stosuje się zawsze tematyczny wyraz 'ktoś', byty te mogą być odróżniane za pomocą subskryptów $i, j$, ... Głównymi ich odpowiednikami w języku naturalnym są imiona własne (tak pisał o tym także prof. Adam Nowaczyk). Otóż można powiedzieć, że ‘ja' jest oznaczeniem desygnatu wyrażenia 'ktoś’ z pierwszym z subskryptów; można sobie wyobrazić, że byłby to subskrypt $i$ stojący na początku szeregu subskryptów. Realny quasi-subskrypt 'ja' jest nieoddzielny od namacalnego organizmu mówiącego; ten organizm jest wprowadzony do gry nieodwołalnie. O tyle zaś jest on wprowadzony milcząco, że semantyka ogranicza się tu do tego, co pokrywa się z pojęciem 'ktoś'.

Wypada więc uznać, że ja jest istotnie, jak to niejednemu świtało, wyrażeniem absolutnie i unikalnie sui generis. Przy czym to, że pierwszy subskrypt musi być, w wypadku każdej osoby mówiącej, zarezerwowany dla niej samej, jest rzeczą stuprocentowo naturalną.

Przy takim podejściu trzeba się zgodzić, że powszechnie przyjęty termin pierwsza osoba jest dobrany idealnie. Sugeruje on trafnie arystotelejską konieczną wielość ,entelechii”, a zarazem ich uporządkowanie szeregowe ze względu na praktyczne wymagania mowy. Jest też w korzystnym kontraście z niefortunnymi dywagacjami Wittgensteina na temat ,granicy świata” i „,solipsyzmu”, dywagacjami, jakie snuł on na kanwie zaimka 'ja' (poprzedzały te jego roztrząsania wielorakie, też mało fortunne, medytacje na temat ,jaźni”; przykłady znamy dobrze, m.in. jako obecne w polskiej filozofii romantycznej).

Przedłożone ujęcie dobrze harmonizuje również z takim oto faktem (dodam tu drobny, ale, metodologicznie na rzecz patrząc, godny uwagi szczegół): istnieje zauważalna różnica (pragmatyczna) między interesującq wypowiedzią, która brzmi: Stalin powiedział tam o sobie Stalin. (dyktator lubił to robić), a zabawna niby-informacja o kształcie: Stalin powiedziat tam o sobie 
ja. Podanie tej ostatniej obserwacji językowego zachowania Stalina jako wartej odnotowania przyszłoby do głowy pewnie tylko głupawemu lingwiście.

I jeszcze jedno pytanie, które postawię, jak to się mówi, „poza konkursem". Czy istnieje jakieś specjalne oznaczenie $d r u g i$ ej osoby, oznaczenie inne niż wyrażenie $t y$, które jest sytuacyjnie zmienne i pod tym względem zasadniczo różne od ja? (Skądinąd to wyrażenie, wyrażenie ty, wymagałoby osobnego omówienia.) Odpowiedź brzmi: tak; w polszczyźnie jest to dla mężczyzny wybrana, dla kobiety - wybrany.

I jest wreszcie dalsza nieunikniona szczególna osoba „ekstra”, którą trzeba ustawić przed wszystkimi innymi. Jest to Bóg. Jej najtrafniejszym nazwaniem jest angielskie the Nameless - Bezimienny. Może chodziłoby tu o coś w rodzaju subskryptu zerowego.

\section{Bibliografia}

BogusŁawski A., 1973, O analizie semantycznej, Studia Semiotyczne IV, s. 47-70.

Bogustawski A., 1977, Problems of the Thematic-Rhematic Structure of Utterances, Warszawa: PWN.

Bogustawski, A., 1991, This, w: M. Grochowski (red.), Problemy opisu gramatycznego języków słowiańskich, Warszawa: Wyd. SGGW, s. 23-30.

BogusŁawski, A., 1998, Science as Linguistic Activity, Linguistics as Scientific Activity, Warszawa: Katedra Lingwistyki Formalnej Uniwersytetu Warszawskiego.

Nowaczyк A., 1999, Gramatyka i prawda, Warszawa: Polskie Towarzystwo Semiotyczne.

WierzBicka, A., 1969, Dociekania semantyczne, Wrocław: Ossolineum.

Wittgenstein, L., 1921/1963, Tractatus logico-philosophicus. Logisch-philosophische Abhandlung, Frankfurt am Main: Suhrkamp.

\section{A note on TRS and Wittgenstein's thesis 7}

\section{( s u m m a r y)}

The author reflects upon a possible empirical interpretation of Wittgenstein's well known thesis 7 in his Tractatus, as applied to some problems encountered when dealing with TRS.

The most general idea is that TRS is what 'shows', in Wittgenstein's sense, rather than what can be rendered in terms of words; the reason being the threatening infi- 
nite regress behind any attempt at reducing the phenomena of TRS to primitive concepts as represented by definite segmental units.

Subsequently, the author touches upon certain more specific themes in the relevant domain. One of them is the problem of how to account for non-restrictive attributes or "appositions". The author stresses the fact that they do not yield to interpretation in terms of something $p$ such that 'the speaker said that $p$ '.

Another issue is that of an adequate interpretation of ' $I$ '. The author shows irreparable inadequacies inherent in Wierzbicka's as well as in his own (previous) accounts of 'I'. According to his new proposal, 'I' is equivalent to 'someone' with the first subscript (in an arbitrary list of subscripts) appended to the organism / body of the current speaker; the latter just shows in Wittgenstein's sense. 